\title{
TANYAGONDNOKOK KOMÁDITÓL HAJDÚNÁNÁSIG
}

\author{
Orbán Szabolcs Gergely
}

\begin{abstract}
Absztrakt: Az alföldi tanyák sajátos kultúrájukkal, életformájukkal, évszázados értékeikkel egyedülálló településformák Európában. A tanyán való élet mindig is meglehetősen deprivált volt, hiszen a fenntarthatóság érdekében rengeteg hátráltató körülménnyel kellett az ottlakóknak megbirkózniuk. Az elmúlt évtizedekben a lakók kiöregedtek, az utódok, a fiatalabb generációk számára pedig már nem vonzóak a tanyák által nyújtott lehetőségek, így mind az ott lakók, mind a lakóegységek száma fokozatosan csökken. Az idősebb lakók életének megkönnyítése, illetve az utódok helybentartása melletti küzdelemben a tanyagondnok az, aki felveszi a harcot egyszemélyben, a tanyagondnoki szolgáltatás, mint szociális alapszolgáltatás keretében. Tanulmányom elsődleges célja aktuális adatok szerzése volt a Hajdú-Bihar megyében található tanyagondnoki szolgáltoknál tevékenykedő tanyagondnokok személyére, összetételére, képzettségére, ellátási területére és ellátottaira vonatkozóan, másodsorban pedig arra kerestem a választ, hogy ezek a szakemberek hogy ítélik meg a tanyák jövőjét. A kutatás során megkerestem Hajdú-Bihar megye összes tanyagondnokát, akiket egy kérdőíven kérdeztem meg, továbbá néhányukkal, illetve a tanyagondnoki szolgáltatást nyújtó fenntartókkal interjúkat készítettem, mely anyagokból egy önállóan elkészített adatbázist állítottam össze.
\end{abstract}

Abstract: The homesteads of the Alföld are unique settlements in Europe with their specific culture, lifestyle and centuries-old values. Life on the homesteads has always been quite deprived, as the residents had to cope with a lot of backlogs in order to be sustainable. In recent decades, residents have grown older and the opportunities provided by homesteads are no longer attractive to offspring and younger generations, so the number of residents and units is gradually decreasing. In the struggle to make life easier for older residents and to maintain offspring, the homestead janitor is the one who fights one-on-one with the parenting service as a basic social service. The primary purpose of my study was to obtain up-to-date information on the identity, composition, qualifications, area of homestead janitors of the material security service providers in Hajdú-Bihar County, and secondly, to find out how these professionals view the future of the homesteads. In the course of the research I contacted all the homestead janitors of Hajdú-Bihar County, who I asked through a questionnaire, and interviewed some of them and the maintainers providing the homestead janitors service, from which I made a self-made database.

Kulcsszavak: tanya, tanyagondnok, képzettség, idősek, fiatalok, jövőkép

Keywords: homestead, homestead janitor, education, senior citizens, young people, vision

\section{Bevezetés}

A tanya úgy él az emberek fejében, mint egy, a zárt településtől távol eső, hátrányos infrastruktúrával rendelkezổ településforma, ahol általában mezőgazdasággal foglalkoznak (Mészáros, 1989). Szerepük azonban az elmúlt évtizedekben gyökeresen megváltozott, nagyrészükben már nem folyik mezőgazdasági termelés, lakóegységekké váltak, olyanokká, ahol a lakók jobbára kiöregedtek, az utódok, a fiatalabb generációk számára pedig már nem vonzóak a tanyák által nyújtott lehetőségek (Romány, 1973). Valójában a tanyai viszonyokról és életformáról manapság nem sokat tudunk, azt pedig, hogy miként lehet ott élni, milyen nehézségekkel küzdenek az ott lakók, föleg a magukra maradt, beteges, vagy éppen hátrányos helyzetű tanyán élők, akik számára igen fontos lenne a segítség és milyen módon járul hozzá ehhez tanyagondnokain keresztül a tanyagondoki szolgálat, 
éppoly érdekes és fontos kérdések mind a szakmának, mind a téma iránt érdeklődőnek. Tanulmányom elsődleges célja aktuális adatok szerzése volt a HajdúBihar megyében található tanyagondnoki szolgáltoknál tevékenykedő tanyagondnokokra, képzettségükre és ellátottaikra vonatkozóan, másodsorban pedig arra kerestem a választ, hogy ezen szakemberek, akik napi szinten a tanyalakók között élnek, hogyan látják igényeiket, és tapasztalataik alapján hogy ítélik meg a tanyák jövöjét.

\section{A tanyagondnoki munka története}

A tanya fogalmát nagyon sokan igyekeztek már meghatározni, valamilyen szempontból megmagyarázni, kategorizálni, de bármelyik meghatározást is néznénk, mindegyikben szerepelnek fontos, nagyon jellemző meghatározó elemek, amelyek jól jellemzik ezt a lakóegységet, azonban összefoglalva a fogalmakat az biztosan kijelenthető, hogy a magyar alföldi tanya egy nagy hagyományú, sajátos települési, gazdálkodási, társadalmi létforma és a természettel összhangban lévő ökológiai rendszer egyszerre (Csatári, 2004).

A falu- és a tanyagondnokság gondolatát Kemény Bertalan fogalmazta meg az 1980-as években, majd 1989-ben elnökségével megalakult a Falufejlesztési Társaság. 1991-ben indította az ágazati minisztérium azt az évente ismétlődő, meghívásos pályázat-sorozatot, amelyet évről-évre újabb megyékre terjesztettek ki, így 1998 óta, időszakosan már az ország összes érintett települése pályázhat falu- és tanyagondnoki szolgálatok kiépítésére (Duró, 2018). 2000-ben a falugondnoki egyesületek és a Falufejlesztési Társaság közösen megalapították a Magyar Tanyaés Falugondnoki Szövetséget, megyénkben ugyanebben az évben alakult meg Hutóczki Imre fülöpi, akkor még falugondnok vezetésével a Hajdú-Bihar Megyei Falu- és Tanyagondnokok Egyesülete.

Kiragadva a Szociális Törvény 60. § (1) bekezdéséből láthatjuk, hogy „a faluilletve a tanyagondnoki szolgáltatás célja az aprófalvak és a külterületi vagy egyéb belterületi, valamint a tanyasi lakott helyek intézményhiányából eredổ hátrányainak enyhítése, az alapvetổ szükségletek kielégítését segítổ szolgáltatásokhoz, közszolgáltatásokhoz, valamint egyes alapszolgáltatásokhoz való hozzájutás biztosítása, továbbá az egyéni, közösségi szintü szükségletek teljesítésének segítése." A törvény szövegéböl kitünik továbbá az is, hogy a falu- illetve a tanyagondnoki munka igen közel áll egymáshoz, ezeket azonban elhatárolja a területi elhelyezkedés, melyről a 60. §. (3) bekezdésében írnak, vagyis a „tanyagondnoki szolgáltatás legalább hetven és legfeljebb négyszáz lakosságszámú - külön jogszabályban meghatározott - külterületi vagy egyéb belterületi lakott helyen müködtethetô." Az alábbi összegzés alapján látható, hogy milyen számban és milyen arányban müködnek ezek a szolgáltatások megyei szinten hazánkban. (Lásd: 1. ábra) 


\section{1. ábra: A falu- és tanyagondnoki szolgáltatások megyei leosztásban Magyarországon}

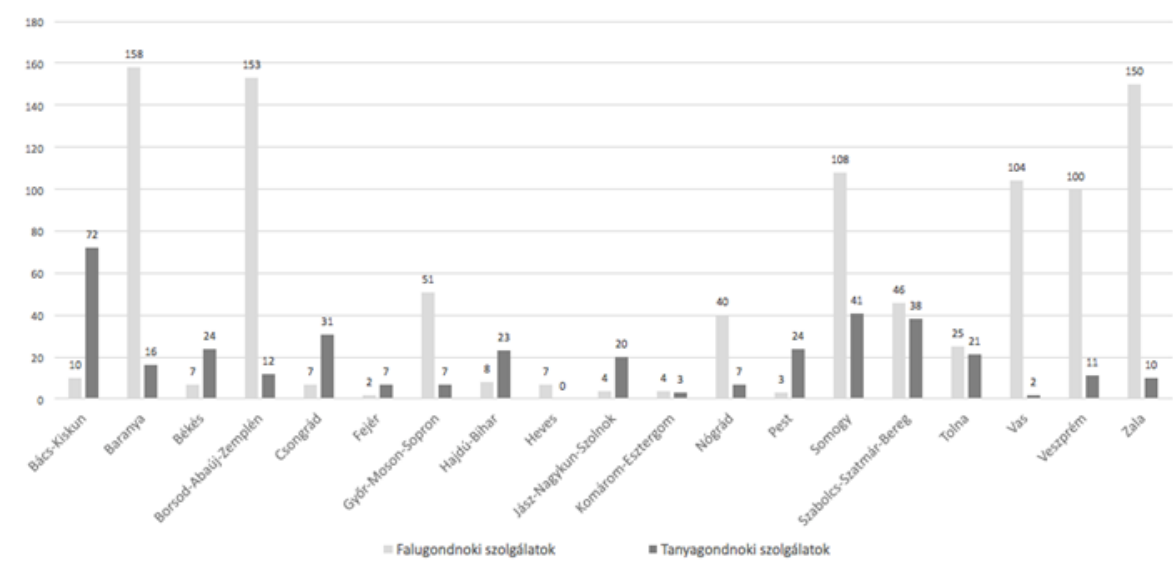

Forrás: A szerző saját szerkesztése / Orbán (2019)

Napjainkban sok az olyan tanya, amelyen magát szinte ellátni képtelen idős házaspár, vagy egyedülálló személy él. Az idős tanyalakók általában őslakos tanyaiak, hajdan gazdálkodtak, de megöregedtek és, vagy anyagi okok, vagy a megszokás miatt a tanyán rekedek. Sorsuk a teljes társadalmi kirekesztődés, így égető szociális gondot jelentenek az anyatelepüléseknek. A tanyagondnoki szolgáltatás segítségével az ellátást igénylök számára lehetőség adódik arra, hogy mindennapjaikat a települési hátrányok ellenére megszokott lakó környezetünkben, saját otthonukban töltsék, fizikai állapotuk, családi helyzetük megváltozása esetén is minél később vagy egyáltalán ne szoruljanak intézményi, szakosított ellátásra, ezáltal biztonságban és méltósággal élhessék le életüket. Ebben nyújtanak segítséget a tanyagondnokok, akik munkájuk során közremüködnek az étkeztetésben, a házi segítségnyújtásban, a közösségi és a szociális információk szolgáltatásában, háziorvosi rendelésre, egyéb egészségügyi intézménybe szállítják a tanyalakókat, gyógyszerkiváltást és a gyógyászati segédeszközökhöz való hozzájutást biztosítják, olykor közösségi, müvelődési, sport- és szabadidős tevékenységeket szerveznek, az egyéni hivatalos ügyek intézését segítik, lakossági igényeket továbbítanak az illetékesek felé, vagy egyéb lakossági szolgáltatásokban, illetve egyéb alapszolgáltatások biztosításában müködnek közre, persze a fenntartók ezeket a feladatokat a települési sajátosságoknak megfelelően kiegészíthetik, melyre a tapasztalatok szerint nagyon sok esetben sor is kerül.

\section{A vizsgálat módszere}

A tanyagondnokok munkája és odaadása nélkül a tanyán lakók életminősége komoly hátrányt szenvedne, ezért cikkemben elsősorban arra törekedtem, hogy feltárjam megyénkben azt, hogy ezt a feladatot hol és mekkora arányban, milyen képzettségü szakemberek végzik, továbbá, hogy jellemzően kik és milyen arányban veszik igénybe a szolgáltatást. Másodsorban arra kerestem a választ, hogy a tanyagondnokok hogyan látják a tanyán lakók igényeit és miként vélekednek a 
helybenmaradásról és a tanyák jövőjéről. Ezt a feldolgozást egy nagyobb kutatás keretében 2019. júliusa és 2019. októbere között végzett kérdőívezés során kapott eredményekből történő adatelemzés keretében hajtottam végre, melynek alapját a Hajdú-Bihar megyében tevékenykedő, összesen 31 tanyagondnok tapasztalatai által kitöltött 6 témakört felölelő kérdöív 2 kiválasztott témája köré építettem melyekben a tanyaiak közléseit összegzik, így választ kaphattam a megfogalmazott kérdésekre. Az adatokat az SPSS szoftver segítségével elemeztem, mely során kereszttábla elemzést is végeztem (Babbie, 2003).

A területi statisztika, és ezen belül a külterületen élők, szükítve pedig a tanyán élők számának meghatározása végett - tekintettel arra, hogy pontos kimutatás sem megyei, sem országos szinten nincs a tanyán lakók száma vonatkozásában - a 2011es Népszámlálás adatait használtam fel, melyet összevetettem a tanyagondnokok által megadott naprakésznek tekinthető adatokkal, melyet a tanyagondnokokkal és a tanyagondnoki szolgáltatást nyújtó fenntartókkal készített interjú sorozatból nyert információk egészítik ki és erősítik meg.

\section{A vizsgálat eredményei}

A cikkem első felében a kérdőív első témája kapcsán a tanyagondnokok korát, iskolai végzettségét, szakmai képesítését, az adott beosztásban töltött idejét, egyéb társadalmi szerepvállalásait, illetve a szolgáltatás fenntartójának típusait írom le, továbbá azt, hogy milyen módon kerültek ebbe a munkakörbe ezek a szakemberek, mennyi ideje vannak ott, illetve, hogy a munka során milyen jellegü jármüveket használnak, mekkora arányban. Ezt követően az ellátási terület lélekszámának nagysága illetve az ellátottak aránya került meghatározásra, mely adatok a külterületen napi szinten jelen lévő szakemberek valós közléseit tartalmazzák, ezeket összevetettem a 2011-es Népszámlálás adataival, amiből erős különbségek rajzolódtak ki, amit legföképpen az elmúlt 8 év elvándorlásainak tudhatunk be, illetve az időközben bekövetkező halálozásoknak, de kategorikusan kijelenthetö, hogy a regisztrált adatok, vagyis a regisztrált tanyákon lakók száma merőben eltér a valós adatoktól.

A lélekszám meghatározását követően lehetséges volt az ellátottak összetételének meghatározása is, melyből következtetni lehet így megyei szinten a tanyák lakóinak kor, illetve társadalmi helyzet szerinti összetételére, melyből megállapítást nyert, hogy az idősebbekből és az egyedülálló aktív korúakból kerülnek ki a gondnokoltak. A tanyák jövőképe tekintetében a második témakörben választ kaptam arra, hogy a nagyszámú idősebb tanyalakók kötődnek a lakóhelyükhöz, megszokás vagy éppen anyagi kényszer alapján, így nagyrészt változtatás nélkül a tanyákon képzelik el további életüket. A lakhatást könnyítő szolgáltatások közül többek között leginkább a tanyákhoz vezető kövesút, a komfortérzetet növelő közművek megléte, a sürü közösségi közlekedés és a jó közbiztonság tenné vonzóbbá a tanyán való életet. Az utódok, a jelenleg tanyán élő fiatalok számára a tanyagondnokok megítélése szerint kevésbé vonzó már a tanyai élet, amit a közeli, vagy helyi megélhetési és munkalehetőségek sem motiválnak eléggé. 


\subsection{A tanyagondnokok}

Hajdú-Bihar megyében jelenleg összesen 31 tanyagondnok látja el szolgálatát 23 tanyagondnoki szolgáltatás keretében. A Debrecen-Bánki Református Egyházközösségnél 4 fö, a Debrecen-Nagycsere-Haláp Református Missziói Egyházközösségnél 3 fö, a Bocskaikert Községi Önkormányzatnál 2 fö, a Fehér Bot Alapítványnál 2 fó, a Nyíradonyi Szociális és Gyermekjóléti Társulásnál 2 fó tanyagondnok végzi el a feladatokat, míg a többi tanyagondnoki szolgáltatás esetében 1 fő áll a tanyalakók rendelkezésére. Ez a leosztás a már említett jogszabályi szabályozásnak megfelelően a külterületi vagy egyéb belterületi lakosság számának arányában alakult ki.

A jogi szabályozás alapján tanyagondnoki munkakörben csak olyan személy foglalkoztatható, akit a foglalkoztatás kezdő időpontjában a munkáltató bejelentett a munkakör betöltéséhez szükséges falu- és tanyagondnoki alapképzésre, majd azt két éven belül elvégzi. A 260 órás tanfolyam jellegü képzés a Nemzeti Erőforrás Minisztérium által engedélyezett központi képzési program alapján történik. A munkábaállás feltétele a befejezett 8 általános iskolai osztály megléte, de megyénkben vannak olyan tanyagondnokok is, akik föiskolai végzettséggel rendelkeznek (2 fö), ellenben a legnagyobb arányban a középfokú (érettségizett), vagy annál alacsonyabb iskolai végzettségü középkorú férfiak (20 fó) látják el ezt a munkát. (Lásd: 2. ábra)

\section{2. ábra: A tanyagondnokok iskolai végzettségének megoszlása}

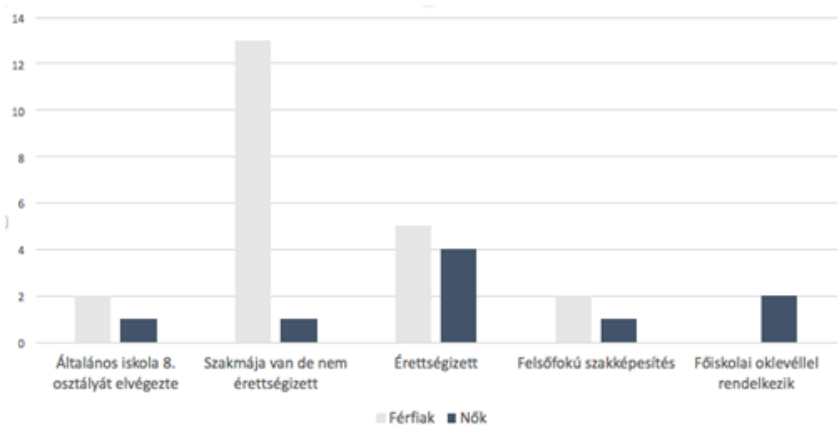

Forrás: A szerző saját szerkesztése / Orbán (2019)

Az iskolai végzettség mellett érdekes a szakmai végzettség is, mert sok esetben nem biztos, hogy a szociális végzettségü szakemberekből lesznek a tanyagondnokok. Többen rendelkeznek kereskedelmi (3 fö), könnyüipari (2 fö), építőipari (4 fö), faipari (3 fö) vagy éppen mezőgazdasági ( 5 fö) szakmai végzettséggel.

Jellemzően ezek a szakemberek más társadalmi szerepeket is vállalnak a településen, ahol szolgálatukat ellátják, melyeket vagy magukkal hoztak, vagy időközben vállaltak fel, bár azok is jellemzően segítő jellegü tevékenységek, a legjellemzőbbek ezek közül a polgárörök (5 fö), müvelődésszervezők (2 fö) és önkéntes tüzoltók (2 fö).

A szakemberek különböző területekről érkeznek, az önkormányzati fenntartók által müködtetett szolgáltatásoknál jellemzően korábban az önkormányzat dolgozói 
voltak más területen, majd figyelembe véve szociális érzékenységüket felkérték őket ezen munka ellátására, de több olyan személy is van, aki ugyancsak tanyán lakik (4 fö), és eleve kötődik ehhez az életformához, míg mások családi kapcsolatok révén, utódlás útján (2 fö) kerültek a szolgálatokhoz. (Lásd: 3. ábra)

\section{3. ábra: Tanyagondnokok szolgálatokhoz kerülésének okai}

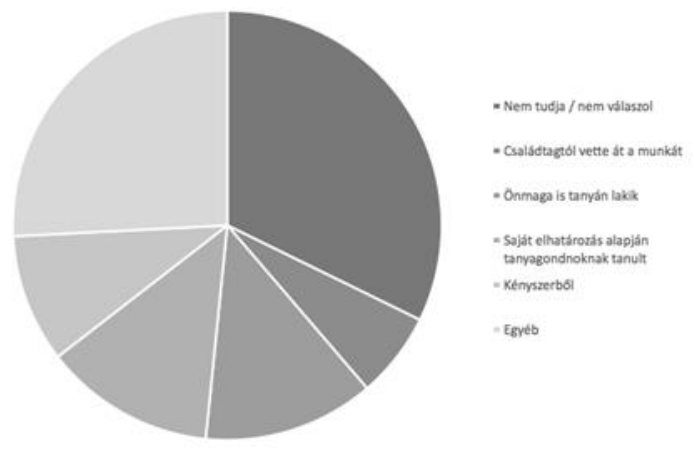

Forrás: A szerző saját szerkesztése / Orbán (2019)

Tekintettel arra, hogy alapjában véve ez az alapszolgáltatás mintegy 20 éve müködik, és inkább csak pár éve alakult ki a végleges formája, inkább a fiatalabb, a néhány éve szolgálatba állt, kevesebb tapasztalattal rendelkező tanyagondokok száma a magasabb (26 fö), míg minden hatodik személy a kezdetektöl van ebben a munkakörben (5 fö), vegyük például Hutóczki Imrét, aki 1998-ban kezdett falugondnokként, és még a mai napig aktív tanyagondnok Fülöpön. (Lásd: 4. ábra)

\section{4. ábra: Tanyagondnokok szolgálatba állásának éve}

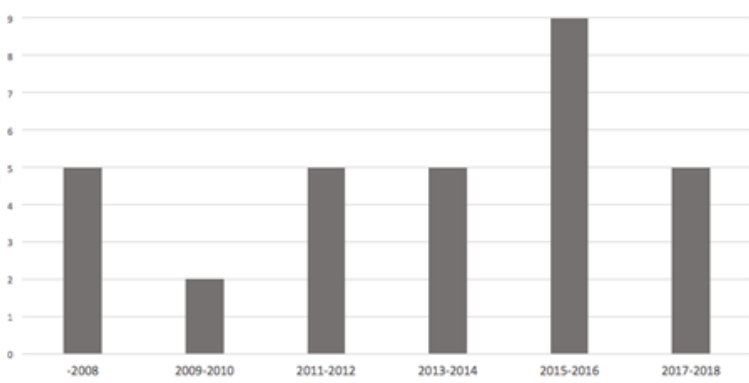

Forrás: A szerző saját szerkesztése / Orbán (2019)

Hivatkozással egy korábbi tanulmányomra megállapítottam, hogy megyénkben az önkormányzati fenntartású tanyagondnoki szolgáltatások a jellemzőek (19), de ezek mellett Debrecen vonzáskörzetében egyházi fenntartókat is találunk (2), továbbá megjelentek újabb típusok, alapítványi (1) illetve nonprofit vállalkozás formájában is (1) (Orbán, 2019).

A megye járásait járva megállapítottam, hogy a szolgálatoknál inkább a pályázati forrásokból beszerzett $8+1$ személyes kisbuszok vannak használatban (15 db), melyek ugyan sok esetben segítik a személyszállítási feladatokat, ellenben a 
külterületi részeken, a földutakon, szélsőséges időjárási körülmények esetén azonban nem alkalmasak a tanyákra való kijutásra. (Lásd: 5. ábra)

\section{5. ábra: A tanyagondnokok által használt jármüvek aránya}

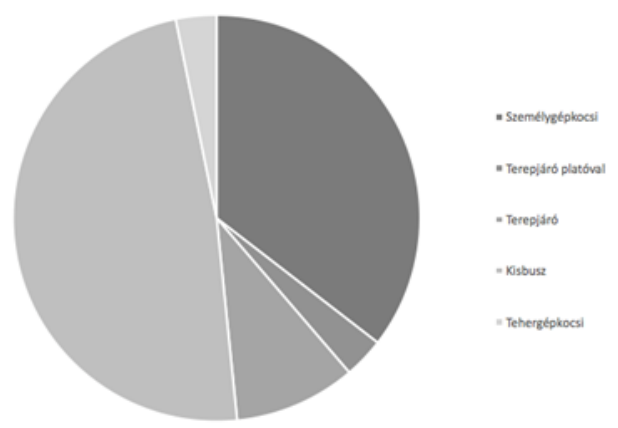

Forrás: A szerző saját szerkesztése / Orbán (2019)

\subsection{Tanyagondnokok ellátási területe}

Hajdú-Bihar megye lakossága a legutóbbi, 2011-es Népszámlálás adatai alapján 539 674 fö volt, ebből a külterületen lakók száma 27450 fö, melyböl tanyákon mintegy 13292 fó élt. 2019-ben a KSH helységnévtárának összesített adatai alapján 7176 fö élt tanyákon. A kutatásban megkérdezett tanyagondnokok szerint, akik pontosan ismerik a területükön lévő aktuális népességet, csak a tanyagondnoki szolgálatokkal lefedett területen él az összegzett adatok alapján körülbelül 7088 fo,, azonban a lakók száma sajnos napról napra csökken. A tanyagondnokokkal folytatott beszélgetések során az is bizonyosságot nyert, hogy a tanyákat az aktív fiatalok hagyják el, az ott maradó idős tanyalakók pedig jobbára kihalnak. Már kevés az anyatelepülésektől távoli, sűrün lakott külterület. Csak Debrecen vonzáskörzetében találunk 500 lakos feletti részeket (Bocskaikert, Nagycsere-Haláp, Debrecen-Bánk). A kisebb lélekszámú települések közelében kevesebb a külterületen lakók száma, ami alól Hortobágy kivétel, ahol a településen a legutóbbi 2018-as adatok alapján mintegy 1 410 fő lakott, a külterületén, a tanyás részeken pedig majdnem 530 fö. (Lásd: 6 . ábra)

\section{6. ábra: Tanyagondnoki szolgálatok által lefedett külterületek népességszáma szolgálatonként}

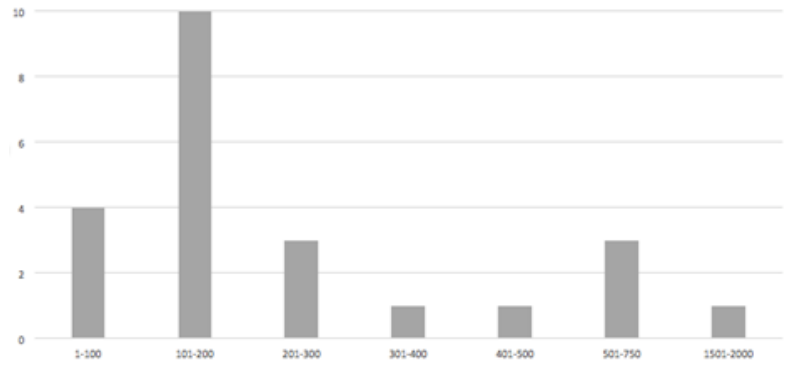

Forrás: A szerző saját szerkesztése / Orbán (2019) 
A külterületeken és a tanyákon lakók nem minden esetben veszik igénybe a tanyagondnoki szolgáltatást, bár ebbe a körbe leginkább csak az aktív korú dolgozók és családjaik tartoznak, amennyiben nem küzdenek hátrányokkal.

A szakemberek nyilatkozatai alapján megállapítást nyert, hogy a rendszeres ellátottak jellemzően vagy anyagi gondokkal, vagy egészségügyi problémákkal küzdenek, esetleg járásukban korlátozottak így valamilyen szempontból mindenképp külső segítségre szorulnak és sokszor napi szinten igénylik a segítséget. Az eseti igénybevevők száma jellemzően alacsonyabb, egyedi esetekben keresik meg a tanyagondnokot és csak bizonyos időközönként, vagy csak bizonyos téren élnek a szolgáltatással, az arányokat az alábbiakban láthatjuk. (Lásd: 7. ábra)

\section{7. ábra: Rendszeres ellátottak száma / Eseti igénybevevők száma szolgálatonként}

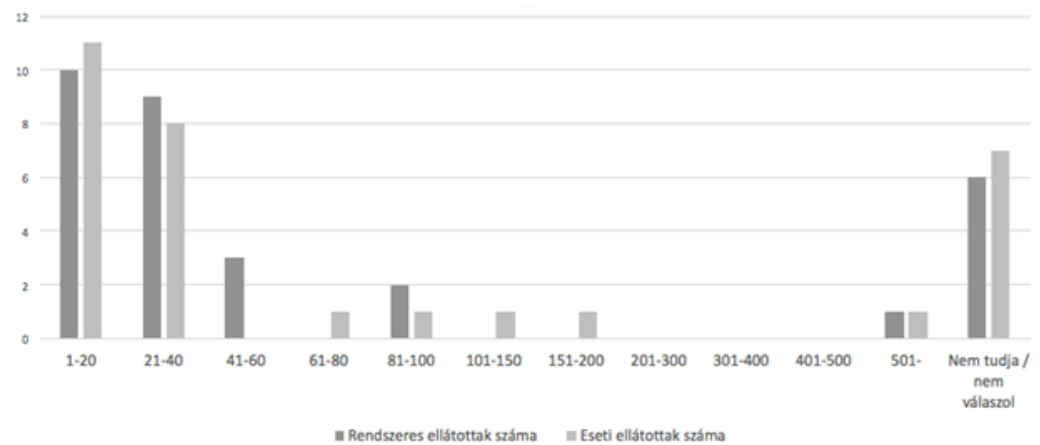

Forrás: A szerző saját szerkesztése / Orbán (2019)

A szolgáltatás igénybevétele dijmentes, feltétele nincs, a segítség nyújtása az arra rászoruló írásbeli vagy akár szóban történő jelzése alapján érkezik. Jellemzően többrétü és minden korosztálynak megfelelő segítségnyújtás történik, de utalva a korábbiakra a tanyagondnokok nyilatkozatai alapján az idősebbek (34\%) és az egyedül élő aktív korúak (14\%) aránya a mérvadó, a teljes igénybevevők majd felét (48\%) teszik ki. (Lásd: 8. ábra)

\section{8. ábra: A szolgáltatást igénybevevők összetétele}

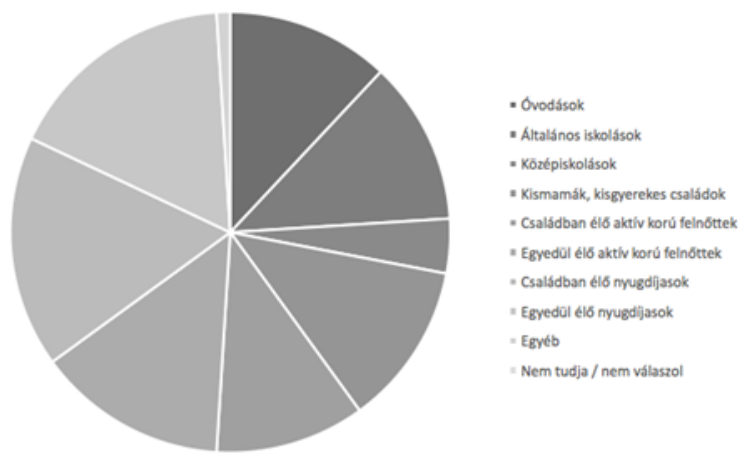

Forrás: A szerző saját szerkesztése / Orbán (2019) 


\subsection{Tanyán maradni, jövőkép}

A fogyasztás szempontjából kétségtelenül hátrány hagyományos lakótanyán lakni. A tanyai mindennapokban több olyan szükséglet jelentkezik, amelyek kielégítése nehézséget jelent az ottlakóknak. A hosszú távon jelentkező esetleges nélkülözés a tanyákon lakókban is megfogalmazza azt a kérdést, hogy tovább maradjanak-e lakóhelyükön. A tanyagondnokok napi szinten együtt élnek a tanyalakókkal és látják az elvándorlási elképzeléseket. A fiatalabbak, akik az összes gondnokolt mintegy harmadát (34\%) teszik ki, a külterülethez közelebb eső településeket veszik célba, és a beköltözésre orientálódnak, hiszen oda köti sokszor őket a megélhetés és a társas kapcsolatok. Jellemzően az idősek azok, akik megszokásból, vagy érzelmi okokból ragaszkodnak a tanyán megszokott élethez. A tapasztalatokból egy új tendencia is kirajzolódik, mégpedig az, hogy vannak lakók, akik a városokból anyagi kényszer miatt költöztek ki a tanyára és kénytelenek ott lakni, mert a településen való életet már nem tudják megfizetni.

Az alapszükségletek kielégítése manapság már kevésnek bizonyul ahhoz, hogy helyben tartsa az elköltözni vágyó lakókat, vagy, hogy az ott felnővök, esetleg a nyugalomra vágyó, kiköltözésben gondolkodó városiak számára vonzóvá tegye ezt a természethez közeli létet. A megkérdezettek tapasztalatai alapján a tanyai életet többek között leginkább az aszfaltozott út, a mindenhol elérhető közmủvek, a sürü közösségi közlekedés és a jó közbiztonság tenné vonzóbbá. (Lásd: 9. ábra)

\section{9. ábra: Mely kényelmi szolgáltatások tennék vonzóbbá a tanyai életet}

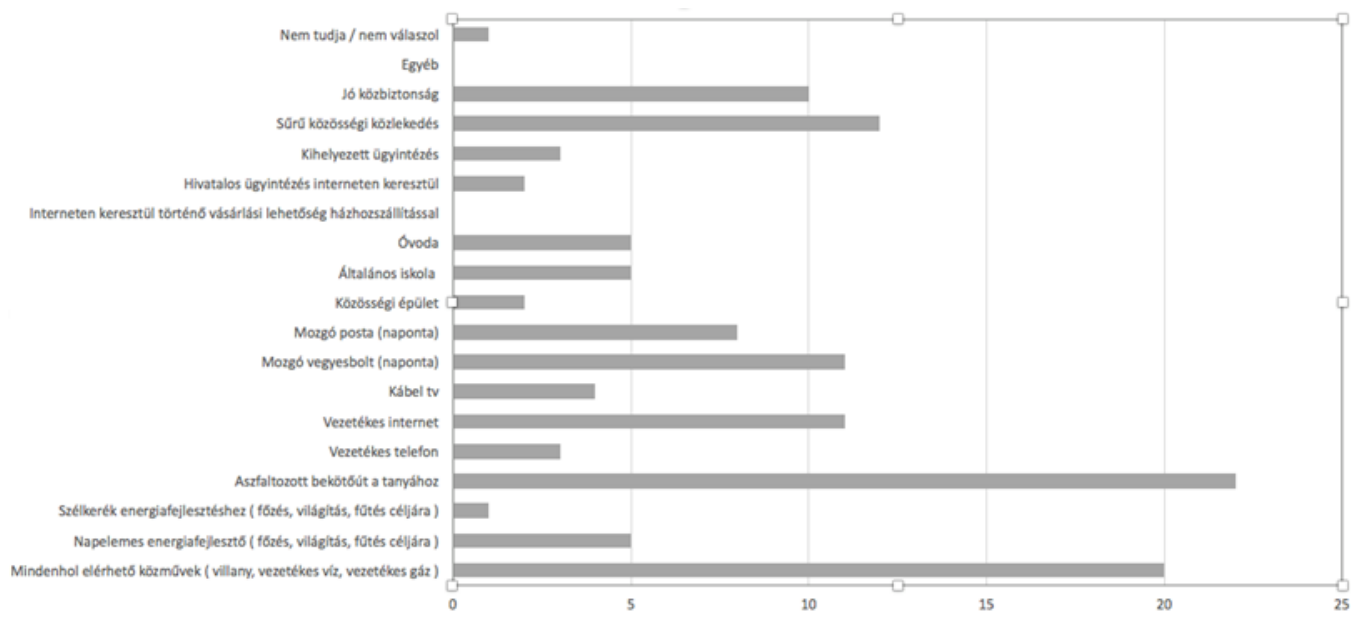

Forrás: A szerző saját szerkesztése / Orbán (2019)

A felnővő fiatalok tanyán folyó élethez való hozzáállása is felemás. Látszik egy távolodó tendencia, vagyis, hogy az életüket már nem a tanyán képzelik el a jövőben (29\%), hiszen az ott folyó munkában már nem (15\%) vagy csak alkalomszerüen (32\%) vesznek részt. (Lásd: 10. ábra) 


\section{0. ábra: Fiatalok jövőképe a tanyán maradásról}

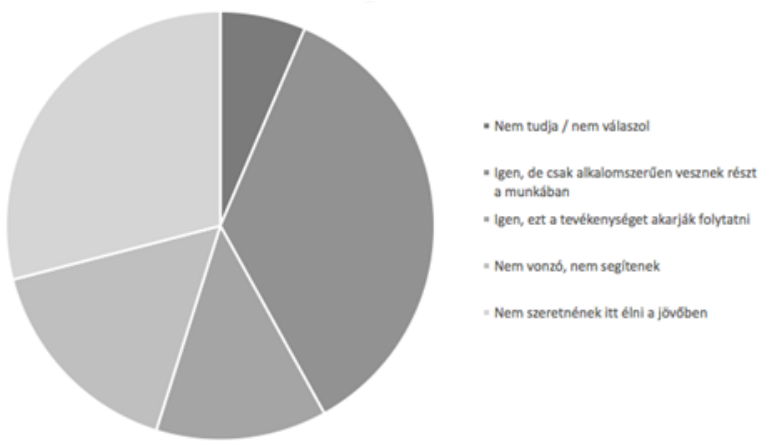

Forrás: A szerző saját szerkesztése / Orbán (2019)

A munka és a közeli munkalehetőségek motiváló hatása is elenyésző, a megélhetés potenciális lehetősége sokszor már kevés ahhoz, hogy a tanyán tartsa az aktív felnőtteket és utódaikat, igaz, akik a mezőgazdaságban dolgoznak azoknak még motiváló tényező a földmunka, de a tapasztalatok szerint már csak minden második ember látja ezt így.

\section{Következtetések}

Az idős, az egyedülálló, a nagycsaládos vagy esetlegesen inaktív tanyán élők számára manapság már csak a tanyagondnokok jelentik az egyetlen segítséget, és az egyetlen kapcsolatot a külvilággal. Ezen szakemberek munkája a mindennapi élethez szükséges élelmezési, egészségügyi, szociális és egyéb szolgáltatások elérésében szinte nélkülözhetetlen. A felvételezett interjúk során megállapítottam, hogy a tanyagondnoki munka egész embert kíván, olyat, aki szívvel és lélekkel tudja ezt csinálni, szociálisan érzékeny, jól tud kommunikálni az emberekkel, elfogadják, elismerik és ami talán a legfontosabb, a végletekig megbíznak benne. Hajdú-Bihar megyében ezt a munkát a legnagyobb arányban középfokú vagy annál alacsonyabb iskolai végzettségü, településükön aktív társadalmi szerepvállalású középkorú férfiak végzik. Az életkort ugyan összefüggésbe lehetne hozni a szolgálatba állás évével, azonban inkább a munkaviszonyt 10 éven belül megkezdők a jellemzőek. A tanyagondnokok naponta róják az utakat és a külterületeket, de a tapasztalatok szerint jármüveik nem felelnek meg minden elvárásnak, vagyis, hogy személyt és tehert is tudjanak szállítani terepen is, ez a szükös anyagi forrásoknak tudható be.

A külterületen lakók száma földrajzi területenként nagyon eltérő, ezzel együtt megyénk tanyás területei tanyagondnoki szolgálatokkal megfelelően lefedettek. A szolgáltatást rendszeresen igénybevevők száma lényegesen magasabb mint az eseti igénybevevők száma, ami igazolja ezen alapellátás létjogosultságát. Leginkább az idősek, majd az egyedül élő aktív korúak aránya a mérvadó, hiszen összesen a gondnokoltak mintegy felét teszik ki. A tanyák jövőképét az ott lakók, illetve az ott felnővő utódok jövőbeli tervei és igényei formálják. Ugyan sok kényelmi szolgáltatás elér már a tanyákra és az infrastruktúra terén is folyamatosan történnek 
fejlesztések, ennek ellenére mégis inkább elvándorlás figyelhető meg a közeli kiépült településekre, mert a fiataloknak már nem vonzó a tanyasi munka és a tanyasi élet.

Az életkörülmények javítása egy jövőbe mutató fontos feladat, hiszen csak így valósulhat meg a jelenlegi tanyai lakosság helyben tartása, azon túl pedig a fiatalok és középkorúak tanyákon való maradásra bírása, illetve odaköltözésének ösztönzése, hiszen a szolgáltatások korszerü és szakszerü működése ezzel garantálhatja a későbbiekben az időskori ellátást a most odaköltözők számára. Ebben a misszióban látnak el fontos feladatot a tanyagondnokok, hiszen jelentősen hozzájárulnak sokszínű tevékenységükkel a szolgáltatást igénybevevők által érzékelt hasznosságához, alátámasztva azzal létjogosultságát (Barakonyi, 2000).

\section{Irodalomjegyzék}

A szociális igazgatásról és szociális ellátásokról 1993. évi III. törvény

A tanyák és tanyás térségek megőrzéséről, fejlesztéséről szóló 49/2009. (V. 27.) OGY határozat

A személyes gondoskodást nyújtó szociális intézmények szakmai feladatairól és müködésük feltételeiről szóló 1/2000. (I. 7.) SzCsM rendelet

Babbie E. (2008): A társadalomtudományi kutatásmódszertan gyakorlata. Balassi Kiadó, Budapest.

Barakonyi K. (2000): Stratégiai menedzsment. Nemzetközi tankönyvkiadó, Budapest.

Csatári B. (2004): A magyarországi vidékiségről, annak kritériumairól és krízisjelenségeiről. Területi statisztika, 44 (2004/6): 532-543.

Duró A. (2018): Tanyás települések és tanya- gondnoki szolgáltatok az Alföldön. A falu, 33 (3): 2132.

Mészáros R. (1989): A tanyák jövője. In: Csatári B. (szerk.): Tanakodás a tanyákról Országos Tudományos Tanyakonferencia Kecskemét, 1989. május 18-19., 63-59.

Orbán Sz. (2019): A Hajdú-Bihar megyei tanyagondnoki szolgálatoktól. A falu, 34 (1): 45-53.

Romány P. (1973): A tanyarendszer ma. Kossuth Kiadó, Budapest.

Vidékfejlesztési program <https://videkstrategia.kormany.hu/download/6/e1/a0000/tanyafejle sztesi_program_végsö_140326.pdf $>$ (2018.10.29.)

Szociális portal $<\mathrm{http}$ ://szocialisportal.hu/intezmenykereso $>$ (2019. 11. 05.) 